\title{
Orphanin FQ Suppresses NMDA Receptor-Dependent Long-Term Depression and Depotentiation in Hippocampal Dentate Gyrus
}

\author{
Wei-Zheng Wei and Cui-Wei Xie ${ }^{1}$ \\ Department of Psychiatry and Biobehavioral Sciences \\ Neuropsychiatric Institute \\ University of California \\ Los Angeles, California 90024-1759 USA
}

\begin{abstract}
We reported previously that orphanin FQ (OFQ) inhibited NMDA receptor-mediated synaptic currents and consequently suppressed induction of long-term potentiation (LTP) in the hippocampal dentate gyrus. This study examines the effect of OFQ on several other forms of long-term synaptic plasticity in the lateral perforant path of mouse hippocampal dentate gyrus. (1) Long-term depression (LTD): a low frequency stimulation $(1 \mathrm{~Hz}, 15$ min) applied to the lateral perforant path induced a long-lasting reduction in the dentate field potentials in slices from 22- to 30-day-old mice. This LTD was sensitive to the NMDA receptor blocker D-AP5, and could be significantly attenuated by bath application of OFQ (1 $\mu \mathrm{M}, 25 \mathrm{~min})$. (2) Primed LTD: induction of LTD in slices from 50- to 65-day-old mice required a priming procedure consisting of multiple high frequency stimulus trains delivered in the presence of D-AP5 before the low-frequency stimulation. OFQ applied during the low-frequency stimulation, but not during the priming trains, blocked induction of primed LTD. (3) Depotentiation: high-frequency train-induced dentate LTP could be reversed by a subsequent low-frequency stimulation. This depotentiation was also attenuated by either OFQ or D-AP5 applied during low-frequency
\end{abstract}

${ }^{1}$ Corresponding author. stimulation. These results, together with our previous findings, suggest that OFQ inhibits bidirectional changes in synaptic strength in the dentate; and its multiple actions on NMDA receptor-dependent, long-term synaptic plasticity might work in tandem to regulate hippocampus-dependent learning and memory.

\section{Introduction}

Orphanin FQ (OFQ), also called nociceptin, is a recently identified endogenous heptadecapeptide that activates the opioid receptor-like (ORL1) receptor in the brain and reportedly induces hyperalgesia and hypolocomotion in rodents (Meunier et al. 1995; Reinscheid et al. 1995). The ORL-1 receptors are highly expressed in the limbic system regions, such as the hippocampus and amygdala (Lachowicz et al. 1995; Anton et al. 1996). Because these brain regions, particularly hippocampus, are known to be important for memory formation and certain types of learning, there has been growing interests in examining the function of the OFQ/ORL-1 system in these areas with regards to the modulation of learning and memory. Our earlier studies showed that application of OFQ strongly inhibited induction of long-term potentiation (LTP) in area CA1 and dentate gyrus of rat hippocampal slices (Yu et al. 1997). Accordingly, an in vivo study demonstrated impairment of spatial learning following intrahippocampal injection of OFQ in rats (Sandin et al. 1997). These findings indicated that OFQ could modulate hippocampusdependent learning and memory negatively, and suppression of activity-dependent, long-term synaptic plasticity might underlie its action. This no-

LEARNING \& MEMORY 6:467-477 @ 1999 by Cold Spring Harbor Laboratory Press ISSN1072-0502/99 \$5.00

$$
\begin{array}{lllllllllllllll}
L & E & A & R & N & I & N & G & \underset{467}{\boldsymbol{Z}} & M & E & M & O & R & Y
\end{array}
$$


tion was supported further by a gene targeting study demonstrating facilitation of CA1 LTP and improved learning and memory in mice lacking ORL-1 receptors (Manabe et al. 1998). Effort has been made to further elucidate the cellular mechanisms underlying OFQ-induced learning deficits. Our most recent study revealed that OFQ inhibited NMDA receptor-mediated synaptic currents strongly via a postsynaptic mechanism in the dentate granule cells (Yu and Xie 1998). Because LTP in the dentate perforant path, both the lateral and medial division, is NMDA receptor-dependent (Colino and Malenka 1993), this finding provided a possible underlying mechanism for impairment of dentate LTP. It also raised several interesting questions. For example, can OFQ suppress other forms of activitydependent synaptic plasticity that are potentially important for information storage in the hippocampus? If so, is the action of OFQ contingent on the NMDA receptor dependence of the plasticity, that is, does OFQ selectively inhibit those requiring activation of NMDA receptors? This study attempted to address these questions by examining the effect of OFQ on low-frequency stimulation-induced long-term depression (LTD) and depotentiation at the lateral perforant path-dentate granule cell synapse in mouse hippocampal slices.

LTD is an activity-dependent, long-lasting decrease in synaptic efficacy (Bear and Malenka 1994). In brain slices from young animals, homosynaptic LTD can be induced by a brief period of low-frequency stimulation (LFS) at $1-10 \mathrm{~Hz}$ in all three hippocampal subregions-CA1 (Dudek and Bear 1992; Mulkey and Malenka 1992), CA3 (Derrick and Martinez 1996; Kobayashi et al. 1996), and dentate gyrus (O'Mara et al. 1995; Wang et al. 1998). The similar LFS protocol, when applied after induction of LTP, can produce depotentiation, a rapid reversal of potentiation to the baseline level (Wagner and Alger 1995; Doyle et al. 1997). Both LTD and depotentiation are considered useful models for experience-dependent persistent reduction in synaptic strength, which may operate together with synaptic potentiation during information processing in the brain ( $\mathrm{Xu}$ et al. 1997, 1998). The underlying mechanisms for both phenomenon, however, have not been well understood. At the Schaffer collateral-CA1 synapse induction of LTD or depotentiation is known to require a moderate rise in postsynaptic $\mathrm{Ca}^{2+}$ following activation of NMDA receptors (Cummings et al. 1996) or metabotropic glutamate receptors (mGLuRs) (Oliet et al. 1997). Similarly, LTD or depotentiation in the dentate medial perforant path is also $\mathrm{Ca}^{2+}$ dependent, but the source of the $\mathrm{Ca}^{2+}$ rise remains controversial, with evidence for the involvement of NMDA receptors (Desmond et al. 1991; Thiels et al. 1996), metabotropic glutamate receptors (mGLuR) (O'Mara et al. 1995), voltage-gated $\mathrm{Ca}^{2+}$ channels (Wang et al. 1997; Wang et al. 1997) and release of $\mathrm{Ca}^{2+}$ from intracellular stores (Wang et al. 1997). Little is known regarding the LFS-induced homosynaptic LTD and depotentiation in the lateral perforant path. An earlier study reported that LTD and depotentiation could be induced in this pathway by a $1-\mathrm{Hz}$ LFS in slices from 4 - to 6-weekold mice (Brandon et al. 1995) but mechanisms for their induction and modulation remain largely unexplored to dae.

Another plasticity model examined in the present study is the priming of LTD. It is well known that induction of LTD in area CA1 is age dependent. Although depotentiation can be induced readily by LFS in mature preparation from $>30$-dayold animals, successful induction of LTD in vitro has been limited to slices from younger animals (Mulkey and Malenka 1992; Mulkey et al. 1994; Wagner and Alger 1995). Application of a brief period of high-frequency stimulation (HFS, 30-100 $\mathrm{Hz}$ ) before the LFS reportedly "primes" the induction of LTD in area CA1 of mature slices (Wexler and Stanton 1993; Hollan and Wagner 1998). It is unclear whether similar protocols would also facilitate LTD in the dentate. Furthermore, the priming of LTD by prior synaptic activity is consistent with the concept of metaplasticity, that is, certain patterns of cellular or synaptic activity can change the ability of synapses to induce subsequent plasticity, whereas not necessarily altering the efficacy of normal synaptic transmission (Abraham and Bear 1996). It is worth further investigating whether this type of plasticity can also be modulated by OFQ in the dentate gyrus.

\section{Materials and Methods}

\section{SLICE PREPARATION}

\section{AND EXTRACELLULAR RECORDINGS}

Transverse hippocampal slices $(500 \mu \mathrm{m})$ were prepared from 22- to 65-day-old male C57 black 6 mice and maintained in a holding chamber with oxygenated artificial cerebrospinal fluid (ACSF) at $30 \pm 1^{\circ} \mathrm{C}$. The ACSF contained $120 \mathrm{~mm} \mathrm{NaCl}, 25$ mм $\mathrm{NaHCO}_{3}, 3.3 \mathrm{~mm} \mathrm{KCl}, 1.23 \mathrm{~mm} \mathrm{NaH}_{2} \mathrm{PO}_{4}, 2 \mathrm{~mm}$ $\mathrm{CaCl}_{2}, 1 \mathrm{~mm} \mathrm{MgSO}_{4}$, and $10 \mathrm{~mm}$ D-glucose (pH 7.4).

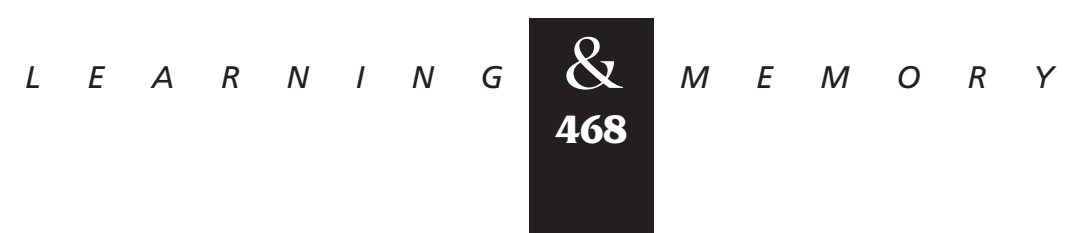


After at least $1 \mathrm{hr}$ incubation in the holding chamber, the slice was transferred to a 2-ml submerged chamber for recording, where it was perfused continuously with oxygenated, warm $\left(30 \pm 1^{\circ} \mathrm{C}\right) \mathrm{ACSF}$ at a rate of $2-3 \mathrm{ml} / \mathrm{min}$ throughout experiments.

The lateral perforant path was stimulated via a sharpened monopolar tungsten electrode positioned in the outer third of the dentate molecular layer. Field excitatory postsynaptic potentials (fEPSPs) evoked by constant-current stimulus pulses (0.1 msec, 30-300 $\mu \AA$ ) were recorded extracellularly from the outer molecular layer using a glass micropipette filled with 2 м $\mathrm{NaCl}(1-8 \mathrm{~m} \Omega)$. Paired pulse tests (50-100 msec intervals) were conducted to ensure that responses evoked were from the lateral perforant path, which showed clear paired pulse facilitation in contrast to the paired pulse depression in the neighboring medial perforant path (McNaughton 1980).

\section{EXPERIMENTAL DESIGN}

Field potentials were evoked at various stimulus intensities to determine the stimulation-response relationship at the beginning of each experiment. The stimulus intensity that evoke $40 \%-$ $50 \%$ of the maximum EPSP slope was then chosen for the test pulse and LFS or HFS. The test pulses were delivered at $0.01 \mathrm{~Hz}$ throughout the experiment for baseline recording and monitoring the changes in field potentials after the induction of plasticity by LFS or HFS. An LFS protocol ( $1 \mathrm{~Hz}, 15$ min) was used for induction of LTD. In mature slices from 50- to 65-day-old mice, a priming protocol (Hollan and Wagner 1998) was applied before the LFS to facilitate LTD induction. The protocol included two sets of stimulation, each consisting of three high-frequency trains (HFS, 100 $\mathrm{Hz} / 1 \mathrm{~s})$ at $20 \mathrm{sec}$ intervals, with $15 \mathrm{~min}$ between sets. The priming trains were delivered in the presence of the NMDA receptor antagonist D-(-)-2amino-5-phosphonopentanoic acid (D-AP5, $50 \mu \mathrm{M}$ ) to prevent LTP, and were followed by a LFS $40 \mathrm{~min}$ later to induce LTD. In depotentiation experiments, LTP was first induced by two sets of HFS as was used for priming, except that no D-AP5 was applied during the HFS. After observing a stable LTP for $40 \mathrm{~min}$, the LFS was applied to reverse the potentiation.

OFQ (Phoenix Pharmaceuticals, Mountain View, CA) or the NMDA receptor antagonist D-AP5 was bath-applied at indicated concentrations, starting $10 \mathrm{~min}$ before the train stimulation (LFS or HFS as noted) and continuing through the train stimulation for a total period of $25 \mathrm{~min}$. Applied drugs were washed out immediately after completion of the train stimulation. Changes in synaptic strength were quantified $30 \mathrm{~min}$ after the train in drug-free ACSF and expressed as percent changes from the pre-drug baseline level.

\section{DATA ANALYSIS}

In LTD experiments, changes in fEPSP slopes were quantified $30 \mathrm{~min}$ after the LFS and expressed as percent reductions from the average baseline level collected for $10 \mathrm{~min}$ before the LFS. In depotentiation experiments, HFS-induced LTP was assessed 30 min after the last train, which was set as the pre-depotentiation level; the remaining LTP after the depotentiation was determined $30 \mathrm{~min}$ after the LFS; and all changes in fEPSP slopes were expressed as percent changes from the average baseline level.

The recorded responses were amplified, digitized and stored on computer disks for off-line analysis. The group data were presented as mean \pm s.E., with $n$ value representing number of slices, one from each animal, for each group. Data were first subjected to a one-way analysis of variance (ANOVA) to test for overall statistical significance, and comparisons between groups were then made by student's $t$-tests. Statistical significance was defined as $P<0.05$.

\section{Results}

\section{SUPPRESSION OF LFS-INDUCED LTD BY OFQ AND D-AP5}

In slices from 22- to 30-day-old mice, an LFS (1 $\mathrm{Hz}, 15 \mathrm{~min}$ ) was applied to the lateral perforant path to induce LTD in the dentate gyrus. As demonstrated in Figure 1, this LFS protocol produced a significant reduction in the fEPSP slope, which lasted for at least $30 \mathrm{~min}$ in control slices (31 $\pm 3 \%$ reduction, $n=12$ ). Bath-applied OFQ at $1 \mu \mathrm{M}$ for $25 \mathrm{~min}$ did not affect the baseline responses or the initial reduction of fEPSP slopes immediately after the LFS. The LFS-induced depression, however, recovered much faster in OFQ-treated slices, leaving only $8 \pm 4 \%$ reduction from the baseline $30 \mathrm{~min}$ after the LFS $(n=12, P<0.01$ as compared with the control LTD). The NMDA receptor antagonist D-AP5 was applied in a similar manner to another group of slices ( $50 \mu \mathrm{M}, 25 \mathrm{~min}$ ). LTD in this group

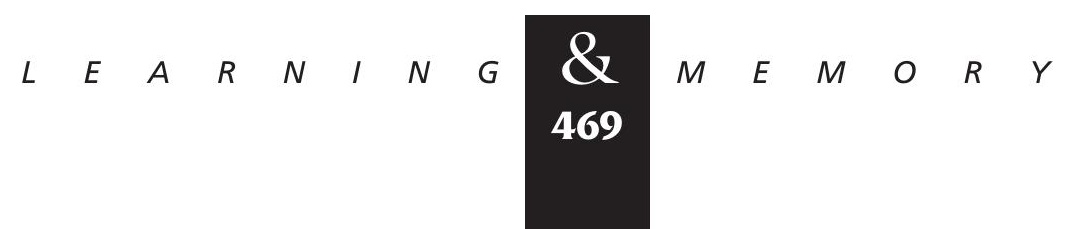


Figure 1: $O F Q$ inhibits the induction of NMDA receptor-dependent LTD at the lateral perforant path-dentate granule cell synapse. Hippocampal slices were from 22- to 30-day-old mice. An LFS was applied at $1 \mathrm{~Hz}$ for $15 \mathrm{~min}$ to induce LTD ( $\square$ ). OFQ or D-AP5 was bath-applied at indicated concentrations for 25 $\min (\boldsymbol{\square}$ or $\Delta)$. Note the stable LTD in control slices $(n=12)$, and significant reduction of LTD in OFQ- or D-AP5treated slices ( $n=12$ and 5, respectively). The sample fEPSPs at the top were recorded before (1) and 30 min after the LFS (2) in slices perfused with control medium, $50 \mu \mathrm{M}$ D-AP5 or $1 \mu \mathrm{M}$ OFQ, respectively. Calibration bars, 2 $\mathrm{mV}, 10 \mathrm{msec}$.
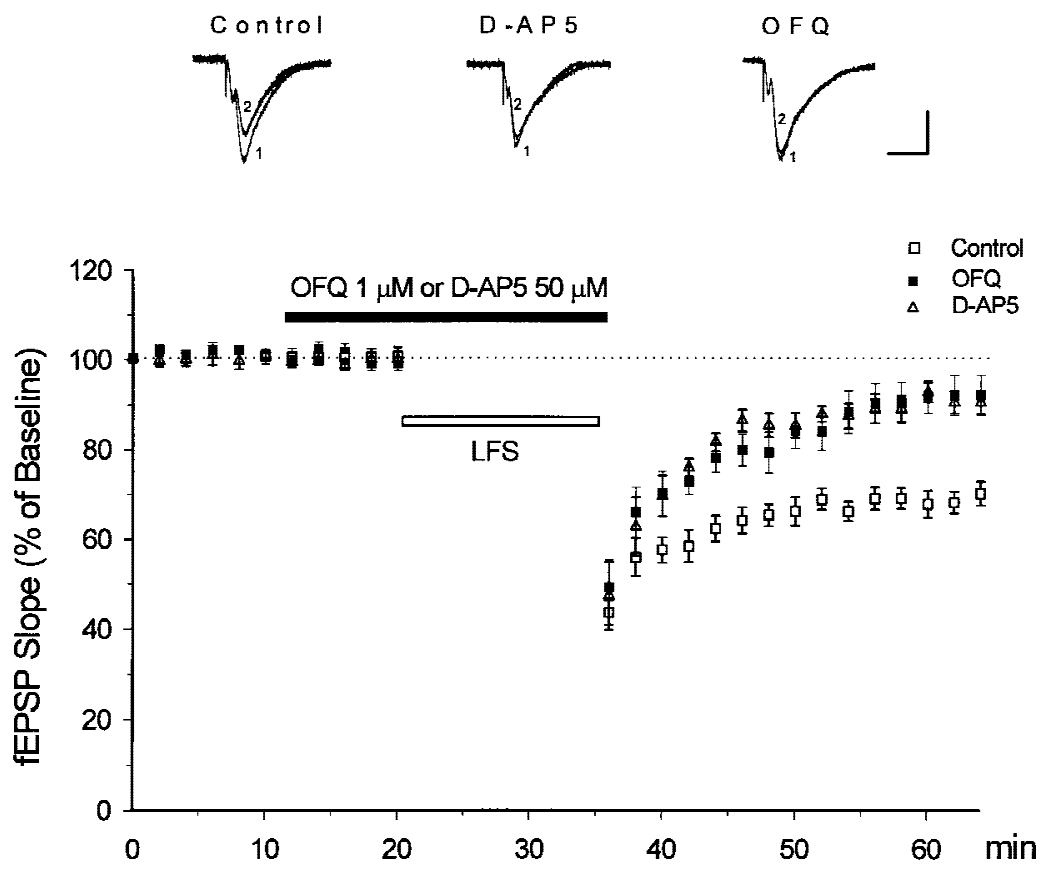

of slices was also substantially suppressed $(5 \pm 3 \%$ reduction $30 \mathrm{~min}$ after the LFS, $n=5, P<0.01$ as compared with the control LTD), though its initial phase was not completely eliminated by D-AP5 (Fig. 1).

\section{THE EFFECT OF OFQ AND D-AP5 ON PRIMING AND PRIMED LTD}

Whereas the LFS protocol routinely induced LTD in young slices, it produced little depression in slices from 50- to 65-day-old mice ( $1 \pm 3 \%$, $n=6$ ). In those mature slices, a priming protocol was applied to facilitate LTD induction, which consisted of two sets of HFS followed $40 \mathrm{~min}$ later by the LFS. As shown in Figure 2, A and B, a significant LTD could be obtained in mature slices treated with this priming procedure $(28 \pm 4 \%, n=8$, $P<0.01$ as compared with the unprimed control group). Because the NMDA receptor antagonist DAP5 (50 $\mu \mathrm{M})$ was routinely applied during the priming trains to prevent LTP, apparently the priming process occurring during the HFS was NMDA receptor-independent. When the perfusion of D-AP5 was extended to cover the period of LFS (Fig. $2 \mathrm{~A}, \mathrm{C})$, however, the induction of LTD was suppressed $(0 \pm 2 \%, n=5)$.

Interestingly, OFQ displayed actions similar to D-AP5 on priming and primed LTD. When $1 \mu \mathrm{M}$ OFQ was applied during the high-frequency prim- ing trains (Fig. 3A,B), the amount of primed LTD was $29 \pm 2 \%(n=5)$, indistinguishable from that in the control slices $(28 \pm 2 \%, n=8, P=0.8)$. In contrast, when OFQ was applied during the LFS (Fig. $3 \mathrm{~A}, \mathrm{C})$, the primed LTD was significantly inhibited ( $4 \pm 4 \%, n=6, P<0.01$ as compared with the controls). Therefore, similar to D-AP5, OFQ did not block the priming event during HFS, nevertheless it suppressed the final induction of LTD during LFS in primed slices.

\section{INHIBITION OF LFS-INDUCED DEPOTENTIATION BY} OFQ AND D-AP5

Multiple HFS to the lateral perforant path induced a long-lasting LTP in control slices from 50to 65-day-old mice. As shown in Figure 4, the LTP in control slices $(n=6)$ was $56 \pm 4 \%$ above the baseline $30 \mathrm{~min}$ after the last HFS and remained at $47 \pm 3 \%$ by the end of experiments $(85 \mathrm{~min}$ after the HFS), with $<10 \%$ decay in nearly $1 \mathrm{hr}$. Application of an LFS after induction of LTP was able to cause a rapid and complete reversal of this otherwise lasting LTP. In the depotentiated slices there was only a $5 \pm 3 \%(n=7)$ potentiation remaining 30 min after the LFS (85 min after the HFS), which was significantly smaller than both the pre-depotentiation level in the same slices $(57 \pm 9 \%, 30 \mathrm{~min}$ after the HFS) and the remaining LTP in control slices $85 \mathrm{~min}$ after the HFS $(P<0.01$ for both comparisons).

$$
\begin{array}{lllllllllllllll}
L & E & A & R & N & I & N & G & \begin{array}{l}
\boldsymbol{Z} \\
\mathbf{4 7 0}
\end{array} & M & E & M & O & R & Y
\end{array}
$$


A

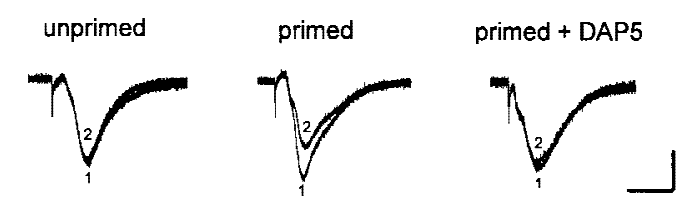

B
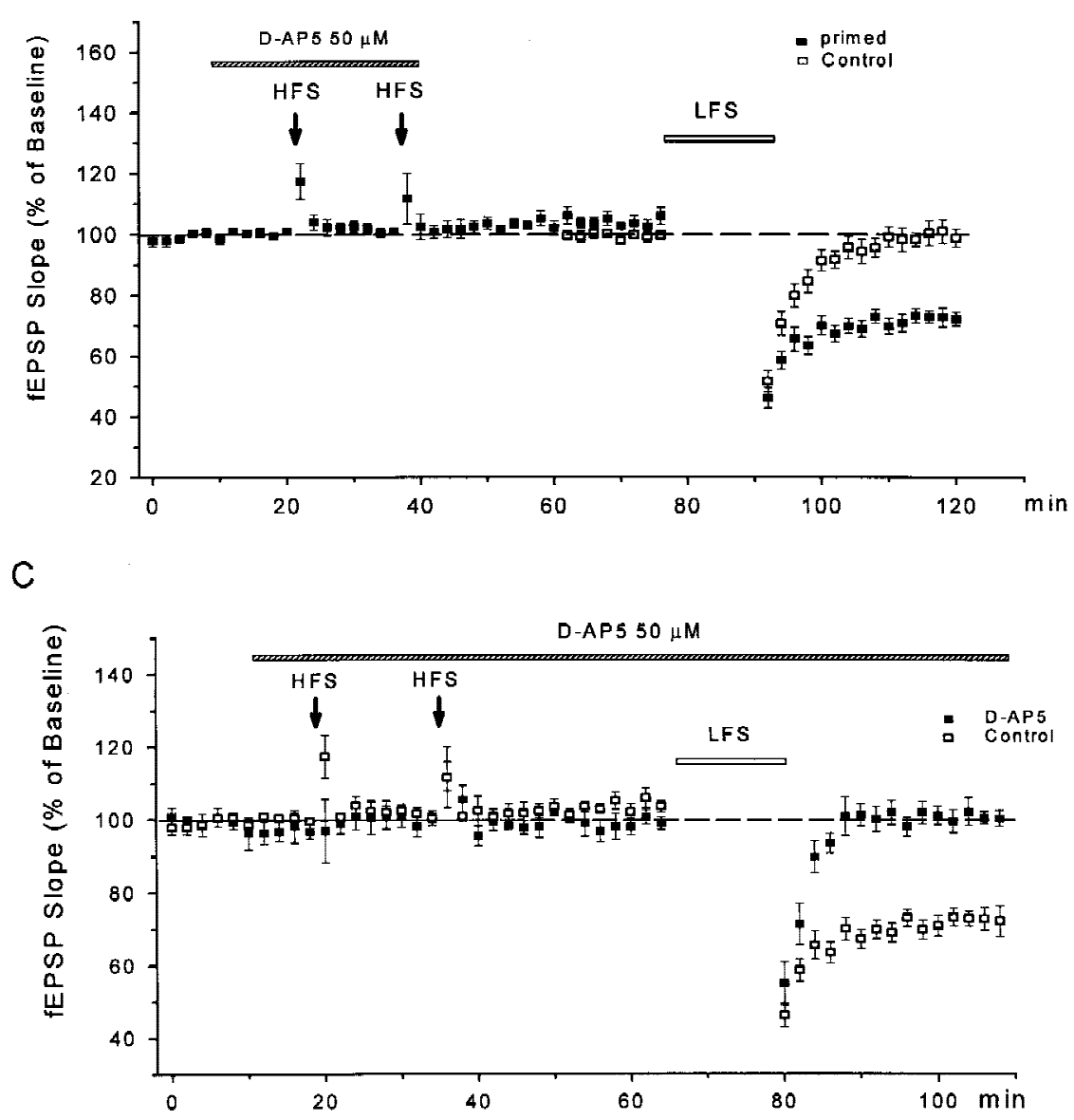

Figure 2: D-AP5 inhibits primed LTD but not priming itself in mature slices from 50- to 65-day-old mice. (A) Sample fEPSPs recorded before (1) and $30 \mathrm{~min}$ after the LFS (2) from unprimed, HFS-primed, and D-AP5-treated (during LFS) primed slices. Calibration bars, $2 \mathrm{mV}, 10 \mathrm{msec}$. (B) Facilitation of LTD induction by prior HFS. Each arrow represents three high-frequency trains $(100 \mathrm{~Hz}, 1 \mathrm{sec})$ at 20 -sec intervals. The control group received no priming trains. (C) Attenuation of primed LTD by D-AP5 when applied during the LFS. D-AP5 was applied during the HFS only (control group) or throughout the experiments (D-AP5 group). Both groups received the priming trains and subsequent LFS. $n=5-8$ for each group.

OFQ (1 $\mu \mathrm{M})$ or D-AP5 (50 $\mu \mathrm{M})$, applied during the LFS, significantly attenuated the depotentiation (Fig. 4). In slices treated with either drug, only a transient reduction in fEPSP slopes was observed after the LFS, which mostly recovered within 20 min. Thirty min after the LFS the remaining LTP was $39 \pm 8 \%$ in OFQ treated slices $(n=7)$ and $31 \pm 9 \%$ in D-AP5-treated slices $(n=4)$. Both values were not significantly different from the control LTP at the corresponding time point ( $47 \pm 3 \%)$, but substantially greater than the remaining LTP in the depotentiation group $(5 \pm 3 \%, P<0.01)$.

\section{Discussion}

BIDIRECTIONAL MODIFICATION OF SYNAPTIC STRENGTH BY OFQ IN THE DENTATE GYRUS

Activity or experience-dependent bidirectional changes in the strength of synaptic connections

$$
\begin{array}{lllllllllllllll}
\hline & E & A & R & N & I & N & G & \begin{array}{l}
\boldsymbol{Z} \\
\mathbf{4 7 1}
\end{array} & M & E & M & O & R & Y
\end{array}
$$




\section{Wei and Xie}

Figure 3: OFQ inhibits primed LTD but not the priming process in mature slices. (A) Sample fEPSPs recorded before (1) and $30 \mathrm{~min}$ after the LFS (2) in slices treated with OFQ during either the HFS or LFS. Calibration bars, $2 \mathrm{mV}, 10$ msec. (B) Application of OFQ during the HFS did not affect the priming effect of HFS on LTD induction. (C) OFQ applied during the LFS significantly suppressed the final induction of LTD in primed slices. The priming protocol, as described in the Fig. 2, was applied in the presence of D-AP5 for all slices. $n=5-8$ for each group.

are believed to underlie learning and memory in the mammalian brain. The direction and magnitude of such changes often are contingent on previous history of synaptic activity and current activity patterns. Behavioral stress has been found to inhibit induction of LTP (Shors et al. 1989; Diamond and Rose 1994) but facilitate LTD in area CA1 of adult rat hippocampus (Xu et al. 1997). Exploration of a new, nonstressful environment induces a persistent reversal of hippocampal LTP in freely moving rats (Xu et al. 1998). Therefore, long-lasting decreases in synaptic efficacy can occur in the brain of behaving animals. Such decreases have been proposed to be crucial for preserving the capacity for change at selected synapses, allowing the detection and storage of new information in the neuronal network (Bear and Malenka 1994; Abraham
A
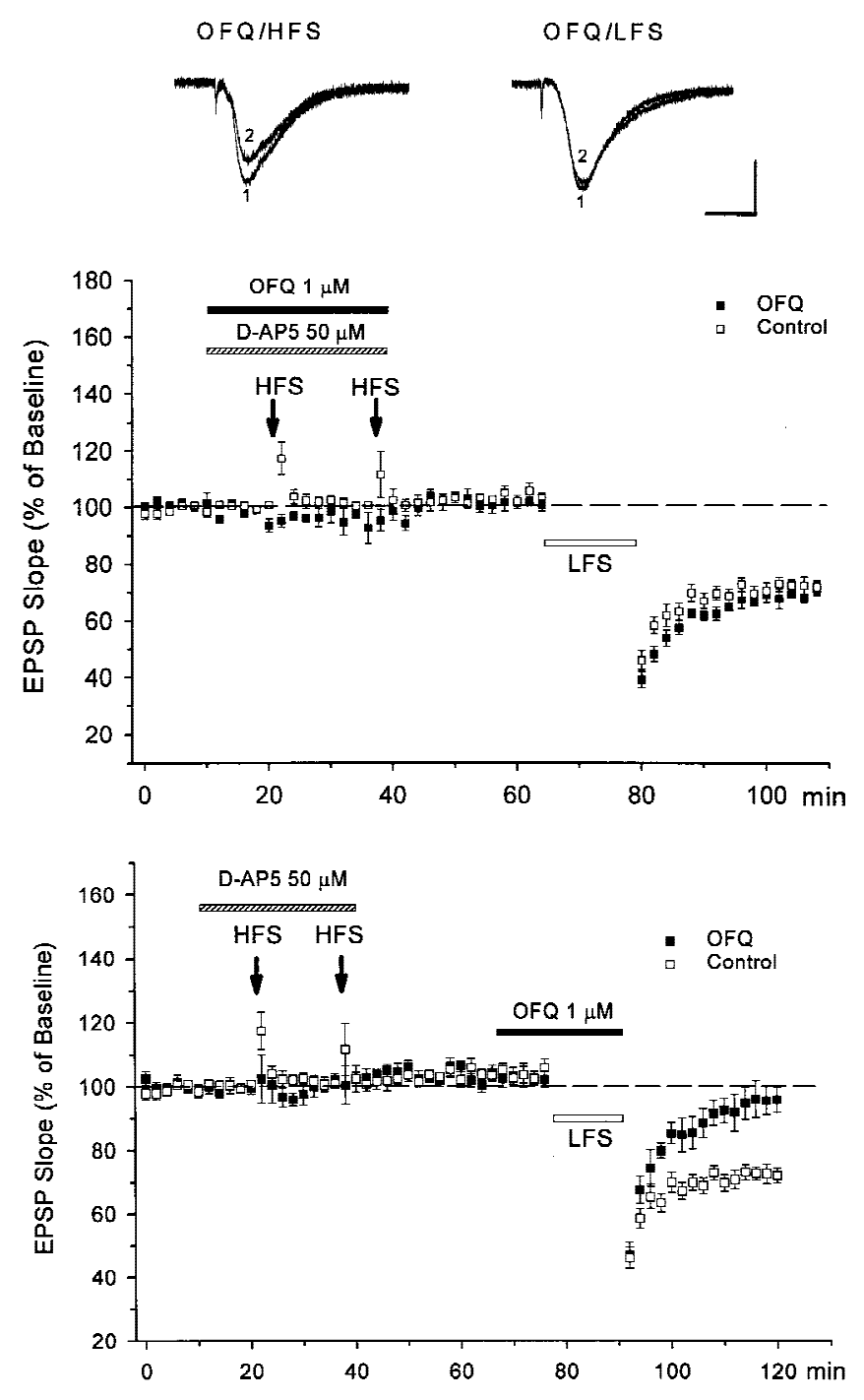

and Bear 1996). In this study OFQ strongly inhibited LTD and depotentiation in the dentate gyrus. Combined with the previous finding that this peptide inhibited LTP induction in the dentate and area CA1 (Yu and Xie 1998), our results indicated that OFQ could suppress both enhancing and suppressive forms of synaptic plasticity, thereby modifying synaptic strength in a bidirectional manner in the hippocampal circuitry. By inhibiting multiple forms of long-term synaptic plasticity at selected synapses, OFQ would be expected to efficiently interfere information processing and storage at these synapses and consequently disrupt hippocampus-dependent learning and memory, as shown in previous behavioral tests (Sandin et al. 1997; Manabe et al. 1998).

To better understand the integrative role of

$$
\begin{array}{lllllllllllllll}
\hline & A & R & N & I & N & G & \mathbf{Q} \\
\mathbf{4 7 2} & M & E & M & 0 & R & Y
\end{array}
$$


A

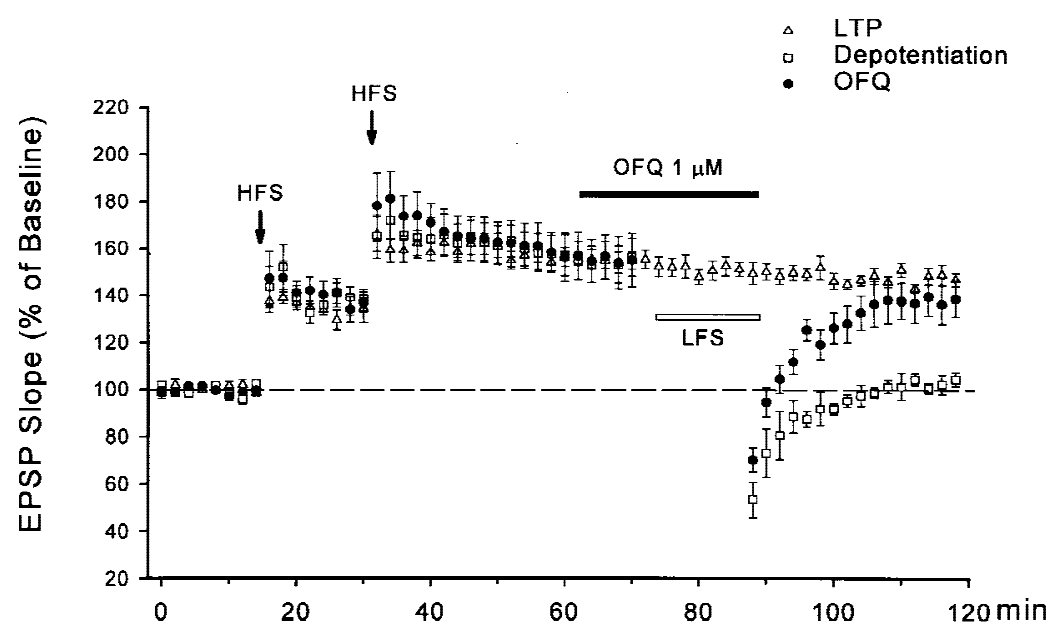

B

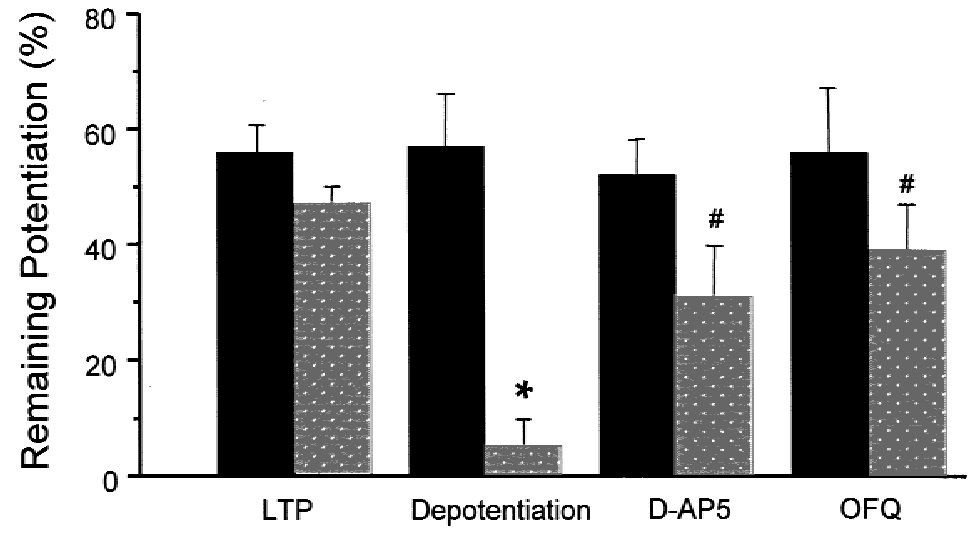

Figure 4. OFQ inhibits NMDA receptor-dependent depotentiation. (A) The time course for multiple HFS-induced long-lasting LTP, reversal of the LTP by a LFS, and the effect of OFQ on depotentiaiton. The same HFS protocol as used for priming was applied in the absence of D-AP5 to induce LTP. The LFS was the same as used in LTD experiments. (B) Summary of depotentiation experiments. The predepotentiation level represents the LTP measured 30 min after the last HFS in all groups (solid bars). The depotentiation was quantified $30 \mathrm{~min}$ after the completion of LFS (stippled bars). For the LTP group that received no LFS, the remaining LTP at $85 \mathrm{~min}$ after the HFS (stippled bars) was used for comparison with other groups. $n=4-7$ for each group. $\left.{ }^{*}\right) P<0.01$ as compared with the LTP group. ( ) $P<0.01$ as compared with the depotentiation group.
OFQ in the modulation of hippocampal function, it may be necessary to consider the proposed role of OFQ as a novel "anti-opiate" peptide in the brain (Mogil et al. 1996). Besides its well documented anti-morphine action in behavioral tests (Mogil et al. 1996; King et al. 1998; Tian et al. 1998), OFQ apparently also has opposite effects to endogenous opioids acting on $\mu$ or $\delta$ receptors in the hippocampus. In contrast to the suppressive effect of OFQ on both LTP and LTD, the endogenous opioids released from the lateral perforant path, mainly enkephalins (Gall et al. 1981), have been shown to facilitate dentate LTP (Bramham et al. 1988; Xie and Lewis 1991, 1995). In addition, activation of enkephalin-containing CA1 perforant projections or local opioid-containing interneurons are believed responsible for a naloxone sensitive LTD in area CA1 (Francesconi et al. 1997). Considering the highly abundant presence of ORL-1 re- ceptors (Lachowicz et al. 1995; Anton et al. 1996; Florin et al. 1997) as well as $\mu$ and $\delta$ opioid receptors (Mansour et al. 1987) in the hippocampus, the interaction between these two peptide systems could have significant influence on the modulation of hippocampal plasticity. In this context, the bidirectional action of OFQ, when operating together with endogenous $\mu / \delta$ opioids or other plasticity enhancers, may provide an efficient means for adjusting the direction and magnitude of plastic changes in synaptic connection, thereby increasing the flexibility and maximal capacity of the system as a whole.

\section{NMDA RECEPTOR-DEPENDENT LTD AND DEPOTENTIATION IN THE DENTATE GYRUS}

Previously filed potential studies have shown that LFS-induced LTD or depotentiation at the me-

$$
\begin{array}{lllllllllllllll}
L & E & A & R & N & I & N & G & \underset{473}{\mathbf{Z}} & M & E & M & O & R & Y
\end{array}
$$


dial perforant path-dentate granule cell synapse is largely NMDA receptor-independent (O'Mara et al. 1995; Trommer et al. 1996; Wang et al. 1997). $\mathrm{Ca}^{2+}$ rise required for LTD induction at these synapses is believed to result primarily from $\mathrm{Ca}^{2+}$ influx via voltage-gated $\mathrm{Ca}^{2+}$ channels and release of intracellular $\mathrm{Ca}^{2+}$ stores following activation of $\mathrm{mGluR}$ (O'Mara et al. 1995; Wang et al. 1997). More recent patch clamp studies, however, have revealed that NMDA receptor-dependent form of LTD can also be induced in the medial perforant path if the postsynaptic neuron is held at mildly depolarized membrane potentials during presynaptic stimulation (Wu and R. Anwyl, pers. comm.). Therefore, similar to the Schaffer collateral-CA1 synapses (Oliet et al. 1997), both NMDA receptor- and mGluR-dependent forms of LTD can be observed at the medial perforant path synapses depending on the experimental conditions.

In the present study LFS-induced LTD and depotentiation at the lateral perforant path-dentate granule cell synapse were significantly attenuated by $50 \mu \mathrm{M}$ D-AP5, which was sufficient for complete blockade of NMDA receptor-mediated synaptic currents in dentate granule cells (Xie et al. 1992). These results indicate that, different from the medial perforant path, LFS-induced synaptic depression in the lateral perforant path seems largely dependent on $\mathrm{Ca}^{2+}$ influx through NMDA receptor channels even under conditions of field potential recordings. Anatomical (Steward 1976), biochemical (Gall et al. 1981; Fredens et al. 1984), and electrophysiological (McNaughton and Barnes 1977) evidence has long demonstrated that the lateral and medial divisions of the perforant path are two distinct pathways. LTP induction in these two pathways is known to be differentially regulated by endogenous opioids, with naloxone blocking LTP in the lateral but not the medial one (Bramham et al. 1988; Xie and Lewis 1991). Therefore, it is not surprising that induction of LTD or depotentiation in these two pathways can display different degree of NMDA receptor dependence. On the other hand, D-AP5 significantly reduced, but did not completely eliminate, LTD and depotentiation in this study. We cannot exclude the possibility that some NMDA receptor-independent mechanisms are also involved, to a minor extent, in synaptic depression in the lateral perforant path. Studies in area CA1 have shown that induction of mGluRdependent LTD can be facilitated by altering the concentrations and ratio of extracellular $\mathrm{Ca}^{2+}$ and $\mathrm{Mg}^{2+}$ (Oliet et al. 1997). It will be of interest to examine in future studies whether under different experimental conditions the potential NMDA receptor-independent mechanisms can be exacerbated for further analysis at the lateral perforant path synapses.

\section{POSSIBLE MECHANISMS FOR THE INHIBITORY} ACTION OF OFQ ON SYNAPTIC DEPRESSION

Because activation of NMDA receptors proved essential for synaptic depression in the lateral perforant path, suppression of NMDA receptor function might constitute a major underlying mechanism for the inhibitory action of OFQ on LTD and depotentiation in this pathway. The effect of OFQ was completely parallel with the action of D-AP5 in several different plasticity tests. Both OFQ and DAP5 inhibited LTD and depotentiation but not the priming of LTD. The selective effect of OFQ on D-AP5-sensitive plasticity was consistent with the previous finding that OFQ strongly inhibited NMDA receptor-mediated synaptic currents in dentate granule cells (Yu and Xie 1998). Together, these results indicate that blockade of currents through NMDA receptor channels on the postsynaptic neurons is the most likely common mechanism for the inhibitory action of OFQ on multiple forms of synaptic plasticity in the dentate gyrus.

It should be noted, however, that inhibition of NMDA receptor currents may not be the sole mechanism responsible for suppression of LTD or depotentiation by OFQ. There are other possible mechanisms, such as OFQ-induced hyperpolarization of dentate granule cells following activation of $\mathrm{a} \mathrm{K}^{+}$conductance (Yu and Xie 1998) and inhibition of voltage-activated $\mathrm{Ca}^{2+}$ channels (Knoflach et al. 1996; Abdulla and Smith 1997). Both effects of OFQ may reduce depolarization-induced $\mathrm{Ca}^{2+}$ influx needed for induction of LTD or depotentiation. In addition, activity of cAMP-dependent protein kinase (PKA) has been found necessary for LTD expression in the lateral perforant path (Brandon et al. 1995). Inhibition of the intracellular cAMP/PKA cascade by OFQ (Meunier et al. 1995; Reinscheid et al. 1995) may be another contributing factor for the suppression of LTD.

A different type of plasticity examined in this study was the priming of LTD. LFS alone was found to induce little LTD in the lateral perforant path of adult animals, suggesting that LTD induction in this pathway possesses similar developmental properties as observed in area CA1. By adopting a HFS protocol used previously in CA1 (Hollan and Wag-

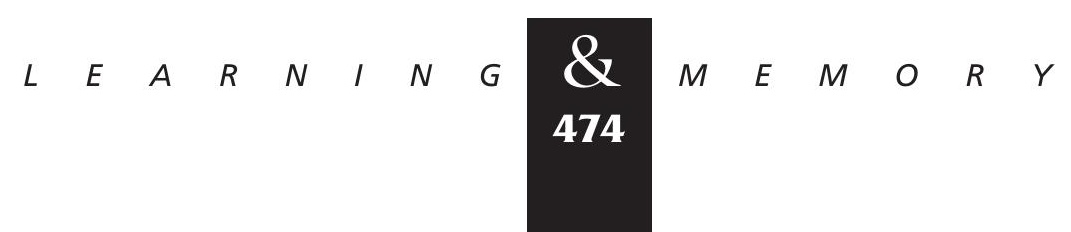


ner 1998), we successfully primed LTD induction in mature slices, indicating that the dentate synapses are also capable of showing this type of metaplasticity. Both OFQ and D-AP5 significantly inhibited primed LTD when applied during the LFS, but neither blocked the priming itself when applied only during the high-frequency priming trains before the LFS. Apparently, the priming mechanisms activated during the HFS were NMDA receptor independent, nor they were affected by OFQ. Using different priming procedures, previous studies have proposed several underlying mechanisms for priming of LTD in the dentate or CA1, such as activation of group 2 mGluR (Manahan-Vaughan 1998), involvement of protein kinase C (Wang et al. 1998), and reduction of GABAergic synaptic inhibition (Wagner and Alger 1996). The critical mechanisms involved in our priming protocol remain to be determined.

In summary, OFQ displayed strong inhibitory action on LFS-induced LTD and depotentiation at the lateral perforant path-dentate granule cell synapse of hippocampal slices. OFQ also suppressed HFS-primed LTD but did not affect the priming process itself. In all these tests, the action of OFQ was completely parallel with the NMDA receptor antagonist D-AP5, suggesting that blockade of NMDA receptor-mediated synaptic currents may be the common mechanisms underlying the inhibitory action of OFQ on multiple forms of synaptic plasticity. The ability of OFQ to alter both LTP and LTD/ depotentiation may enable the peptide to regulate synaptic plasticity in a bidirectional manner, and thereby efficiently affect hippocampus-dependent learning and memory.

\section{Acknowledgments}

This work is supported by National Institutes of Health grants DA08571 and DA05010 (CWX).

The publication costs of this article were defrayed in part by payment of page charges. This article must therefore be hereby marked "advertisement" in accordance with 18 USC section 1734 solely to indicate this fact.

\section{References}

Abdulla, F.A. and P.A. Smith. 1997. Nociceptin inhibits T-type Ca2+ channel current in rat sensory neurons by a G-protein-independent mechanism. J. Neurosci.

17: $8721-8728$.

Abraham, W.C. and M.F. Bear. 1996. Metaplasticity: the plasticity of synaptic plasticity. Trends Neurosci.

19: $126-130$.

Anton, B., J. Fein, T. To, X. Li, L. Silberstein, and C.J. Evans.
1996. Immunohistochemical localization of ORL-1 in the central nervous system of the rat. J. Comp. Neurol. 368: 229-251.

Bear, M.F. and R.C. Malenka. 1994. Synaptic plasticity: LTP and LTD. Curr. Opin. Neurobiol. 4: 389-399.

Bramham, C.R., M.L. Errington, and T.V.P. Bliss. 1988. Naloxone blocks the induction of long-term potentiation in the lateral but not in the medial perforant pathway in the anesthetized rat. Brain Res. 449: 352-356.

Brandon, E.P., M. Zhuo, Y.Y. Huang, M. Qi, K. Gerhold, K.A. Burton, E.R. Kandel, G.S. McKnight, and R.L. Idzerda. 1995. Hippocampal long-term depression and depotentiation are defective in mice carrying a targeted disruption of the gene encoding the RI beta subunit of CAMP-dependent protein kinase. Proc. Natl. Acad. Sci. 92: 8851-8855.

Colino, A. and R.C. Malenka. 1993. Mechanisms underlying induction of long-term potentiation in rat medial and lateral perforant paths in vitro. J. Neurophysiol. 69: 1150-1159.

Cummings, J.A., R.M. Mulkey, R.A. Nicoll, and R.C. Malenka. 1996. Ca2+ signaling requirements for long-term depression in the hippocampus. Neuron 16: 825-833.

Derrick, B.E. and J.L.J. Martinez. 1996. Associative, bidirectional modifications at the hippocampal mossy fibre-CA3 synapse. Nature 381: 429-434.

Desmond, N.L., C.M. Colbert, D.X. Zhang, and W.B. Levy. 1991. NMDA receptor antagonists block the induction of long-term depression in the hippocampal dentate gyrus of the anesthetized rat. Brain Res. 552: 93-98.

Diamond, D.M. and G.M. Rose. 1994. Stress impairs LTP and hippocampal-dependent memory. Ann. NY Acad. Sci. 746: 411-414.

Doyle, C.A., W.K. Cullen, M.J. Rowan, and R. Anwyl. 1997. Low-frequency stimulation induces homosynaptic depotentiation but not long-term depression of synaptic transmission in the adult anaesthetized and awake rat hippocampus in vivo. Neuroscience 77: 75-85.

Dudek, S.M. and M.F. Bear. 1992. Homosynaptic long-term depression in area CA1 of hippocampus and effects of $\mathrm{N}$-methyl-D-aspartate receptor blockade. Proc. Natl. Acad. Sci. 89: 4363-4367.

Florin, S., I. Leroux-Nicollet, J.C. Meunier, and J. Costentin. 1997. Autoradiographic localization of $\left[{ }^{3} \mathrm{H}\right]$ nociceptin binding sites from telencephalic to mesencephalic regions of the mouse brain. Neurosci. Lett. 230: 33-36.

Francesconi, W., F. Berton, A. Demuro, S.G. Madamba, and G.R. Siggins. 1997. Naloxone blocks long-term depression of excitatory transmission in rat CA1 hippocampus in vitro. Arch. Ital. Biol. 135: 34-48.

Fredens, K., K. Stengaard-Pedersen, and L.I. Larsson. 1984. Localization of enkephalin and cholecystokinin

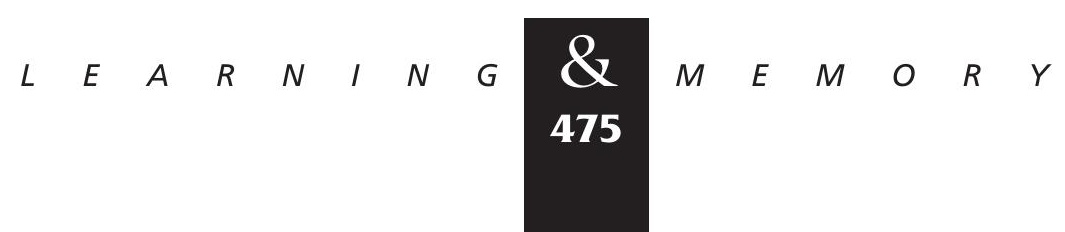




\section{Wei and Xie}

immunoreactivities in the perforant path terminal fields of the rat hippocampal formation. Brain Res. 304: 255-263.

Gall, C., N. Brecha, H.J. Karten, and K.J. Chang. 1981. Localization of enkephalin-like immunoreactivity to identified axonal and neuronal populations of the rat hippocampus. J. Comp. Neurol. 198: 335-350.

Hollan, L.L. and J. Wagner. 1998. Primed facilitation of homosynaptic long-term depression and depotentiation in rat hippocampus. J. Neurosci. 18: 887-894.

King, M., A. Chang, and G.W. Pasternak. 1998. Functional blockade of opioid analgesia by orphanin FQ/nociceptin. Biochem. Pharmacol. 55: 1537-1540.

Knoflach, F., R.K. Reinscheid, O. Civelli, and J.A. Kemp. 1996. Modulation of voltage-gated calcium channels by orphanin FQ in freshly dissociated hippocampal neurons. J. Neurosci. 16: 6657-6664.

Kobayashi, K., T. Manabe, and T. Takahashi. 1996. Presynaptic long-term depression at the hippocampal mossy fiber-CA3 synapse. Science 273: 648-650.

Lachowicz, J., Y. Shen, F.J. Monsma, and D. Sibley. 1995. Molecular cloning of a novel G protein-coupled receptor related to the opiate receptor family. J. Neurochem. 64: $34-40$.

Manabe, T., Y. Noda, T. Mamiya, H. Katagirl, T. Houtani, M. Nishi, T. Noda, T. Takahashi, T. Sugimoto, T. Nabeshima, and $\mathrm{H}$. Takeshima. 1998. Facilitation of long-term potentiation and memory in mice lacking nociceptin receptors. Nature 394: 577-581.

Manahan-Vaughan, D. 1998. Priming of group 2 metabotropic glutamate receptors facilitates induction of long-term depression in the dentate gyrus of freely moving rats. Neurophamacology 37: 1459-1464.

Mansour, A., H. Khachaturian, M.E. Lewis, H. Akil, and S.J. Watson. 1987. Autoradiographic differentiation of mu, delta, and kappa opioid receptors in the rat forebrain and midbrain. J. Neurosci. 7: 2445-2464.

McNaughton, B.L. 1980. Evidence for two physiologically distinct perforant pathways to the fascia dentata. Brain Res. 199: 1-19.

McNaughton, B.L. and C.A. Barnes. 1977. Physiological identification and analysis of the dentate granule cell responses to stimulation of the medial and lateral perforant pathways in the rat. J. Comp. Neurol. 175: 439-454.

Meunier, J., C. Mollereau, L. Toll, C. Suaudeau, C. Moisand, P. Alvinerie, J. Butour, J. Guillemot, P. Ferrara, B. Monsarrat et al. 1995. Isolation and structure of the endogenous agonist of opioid receptor-like ORL1 receptor. Nature 377: 532-535.

Mogil, J.S., J.E. Grisel, R.K. Reinscheid, O. Civelli, J.K. Belknap, and D.K. Grandy. 1996a. Orphanin FQ is a functional anti-opioid peptide. Neuroscience 75: 333-337.
Mogil, J.S., J.E. Grisel, G. Zhangs, J.K. Belknap, and D.K. Grandy. 1996b. Functional antagonism of mu-, delta- and kappa-opioid antinociception by orphanin FQ. Neurosci. Lett. 214: 131-134.

Mulkey, R.M., S. Endo, S. Shenolikar, and R.C. Malenka. 1994. Involvement of a calcineurin/inhibitor-1 phosphatase cascade in hippocampal long-term depression. Nature 369: 486-488.

Mulkey, R.M. and R.C. Malenka. 1992. Mechanisms underlying induction of homosynaptic long-term depression in area CA1 of the hippocampus. Neuron 9: 967-975.

Oliet, S.H., R.C. Malenka, and R.A. Nicoll. 1997. Two distinct forms of long-term depression coexist in CA1 hippocampal pyramidal cells. Neuron 18: 969-982.

O'Mara, S.M., M.J. Rowan, and R. Anwyl. 1995. Metabotropic glutamate receptor-induced homosynaptic long-term depression and depotentiation in the dentate gyrus of the rat hippocampus in vitro. Neuropharmacology 34: 983-989.

Reinscheid, R., H. Nothacker, A. Bourson, A. Ardati, R. Henningsen, J. Bunzow, D. Grandy, H. Langen, F.J. Monsma, and O. Civelli. 1995. Orphanin FQ: A neuropeptide that activates an opioid-like $\mathrm{G}$ protein-coupled receptor. Science 270: 792-794.

Sandin, J., J. Georgieva, P.A. Schott, S.O. Ogren, and L. Terenius. 1997. Nociceptin/orphanin FQ microinjected into hippocampus impairs spatial learning in rats. Eur. J. Neurosci. 9: 194-197.

Shors, T.J., T.B. Seib, S. Levine, and R.F. Thompson. 1989. Inescapable versus escapable shock modulates long-term potentiation in the rat hippocampus. Science 244: 224-226.

Steward, O. 1976. Topographic organization of the projections from the entorhinal area to the hippocampal formation of the rat. J. Comp. Neurol. 167: 285-314.

Thiels, E., X. Xie, M.F. Yeckel, G. Barrionuevo, and T.W. Berger. 1996. NMDA receptor-dependent LTD in different subfields of hippocampus in vivo and in vitro. Hippocampus 6: $43-51$.

Tian, J.H., W. Zhang, Y. Fang, W. Xu, D.K. Grandy, and J.S. Han. 1998. Endogenous orphanin FQ: Evidence for a role in the modulation of electroacupuncture analgesia and the development of tolerance to analgesia produced by morphine and electroacupuncture. Br. J. Pharmacol. 124: 21-26.

Trommer, B.L., Y.B. Liu, and J.F. Pasternak. 1996. Long-term depression at the medial perforant path-granule cell synapse in developing rat dentate gyrus. Dev. Brain Res. 96: 97-108.

Wagner, J.J. and B.E. Alger. 1995. GABAergic and developmental influences on homosynaptic LTD and depotentiation in rat hippocampus. J. Neurosci. 15: $1577-1586$.

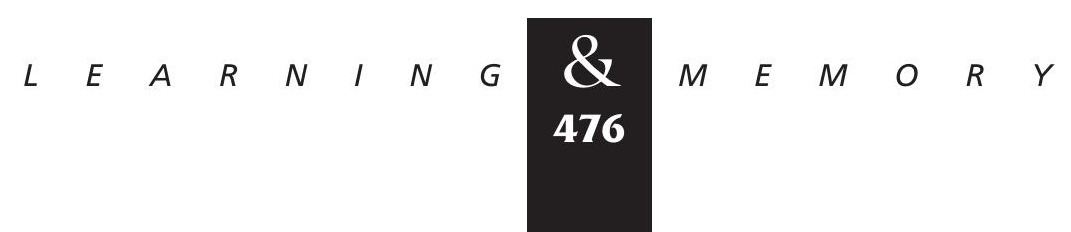


1996. Homosynaptic LTD and depotentiation: Do they differ in name only? Hippocampus 6: 24-29.

Wang, Y., M.J. Rowan, and R. Anwyl. 1997a. Induction of LTD in the dentate gyrus in vitro is NMDA receptor independent, but dependent on Ca2+ influx via low-voltage-activated $\mathrm{Ca} 2+$ channels and release of $\mathrm{Ca} 2+$ from intracellular stores. J.Neurophysiol. 77: 812-825.

Wang, Y., M.J. Rowan, and R. Anwyl. 1997b. LTP induction dependent on activation of $\mathrm{Ni2+-sensitive} \mathrm{voltage-gated}$ calcium channels, but not NMDA receptors, in the rat dentate gyrus in vitro. J. Neurophysiol. 78: 2574-2581.

Wang, Y., J. Wu, M.J. Rowan, and R. Anwyl. 1998. Role of protein kinase $C$ in the induction of homosynaptic long-term depression by brief low frequency stimulation in the dentate gyrus of the rat hippocampus in vitro. J. Physiol.

513: $467-475$.

Wexler, E.M. and P.K. Stanton. 1993. Priming of homosynaptic long-term depression in hippocampus by previous synaptic activity. NeuroReport 4: 591-594.

Xie, C.W. and D.V. Lewis. 1995. Depression of LTP in rat dentate gyrus by naloxone is reversed by $\mathrm{GABA}_{\mathrm{A}}$ blockade. Brain Res. 688: 56-60.

Xie, C.W. and D.V. Lewis. 1991. Opioid-mediated facilitation of long term potentiation at the lateral perforant path-dentate granule cell synapse. J. Pharmacol. Exp. Ther. 256: 289-295.

Xie, C.W., R.A. Morrisett, and D.V. Lewis. 1992. Mu opioid receptor-mediated modulation of synaptic currents in dentate granule cells of rat hippocampus. J. Neurophysiol.

68: $1113-1120$.

Xu, L., R. Anwyl, and M.J. Rowan. 1997. Behavioural stress facilitates the induction of long-term depression in the hippocampus. Nature 387: 497-500.

Xu, L., R. Anwyl, and M.J. Rowan. 1998. Spatial exploration induces a persistent reversal of long-term potentiation in rat hippocampus. Nature : 891-894.

Yu, T.P., J. Fein, T. Phan, C.J. Evans, and C.W. Xie. 1997. Orphanin FQ inhibits synaptic transmission and long-term potentiation in rat hippocampus. Hippocampus 7: 88-94.

Yu, T.P. and C.W. Xie. 1998. Nociceptin/orphanin FQ inhibits synaptic transmission and long-term potentiation in rat dentate gyrus through postsynaptic mechanisms. J. Neurophysiol. 80: 1277-1284.

Received July 8, 1999; accepted in revised form August 22, 1999. 


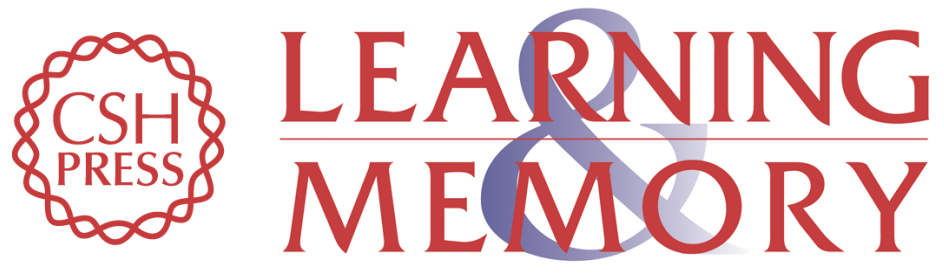

\section{Orphanin FQ Suppresses NMDA Receptor-Dependent Long-Term Depression and Depotentiation in Hippocampal Dentate Gyrus}

Wei-Zheng Wei and Cui-Wei Xie

Learn. Mem. 1999, 6:

Access the most recent version at doi:10.1101//m.6.5.467

References This article cites 53 articles, 10 of which can be accessed free at: http://learnmem.cshlp.org/content/6/5/467.full.html\#ref-list-1

License

Email Alerting Receive free email alerts when new articles cite this article - sign up in the box at the Service top right corner of the article or click here. 